\title{
URGENSI DEMOKRASI DALAM UPAYA PEMBENTUKAN NEGARA IDEAL MENURUT MUHAMMAD SYAHRUR
}

\author{
M. Agus Muwahhidin \\ Institut Agama Islam Negeri Sunan Ampel Surabaya | jurnalsj@gmail.com
}

\begin{abstract}
Democracy for Shahrur is a representation of the concept of shura in modern time. This is because the concept of shura is a part of the dialectic of life. Therefore, It is subject to change, depending on space and time. This is what Shahrur called as the term of value and technical point of shura. As for the pressure point of democracy is subject to shari'ah. Such understanding is evidenced by a definition that democracy is the practice of freedom by a group of humans in accordance with the authority of knowledge, ethics, aesthetics, customs, and religious laws. The urgency of democracy in the efforts to establish the ideal state, which according to Shahrur is called a "secular" countr is a state that bases its legitimacy from the people and not from the religious scholars. It is also a country that does not recognize the existence of the guards of the God's laws. In addition to developing science, democracy can also minimize the potential of friction because it is not talking about primordialism but more about the common interest.
\end{abstract}

Keywords: Democracy, state, Muhammad Shahrur, and Islam.

Abstrak: Demokrasi bagi Syahrur adalah merupakan representasi dari konsep syura pada masa modern. Hal ini dikarenakan konsep syura adalah merupakan bagian dari dialektika kehidupan, oleh karena itu ia tunduk pada perubahan, tergantung pada ruang dan waktu. Hal inilah yang oleh Syahrur disebut sebagai segi nilai dan segi teknis dari syura. Adapun yang menjadi titik tekan dari demokrasi, adalah tunduk pada syari'at agama. Yang dibuktikan dengan definisinya bahwa demokrasi adalah praktik kebebasan yang dilakukan sekelompok manusia sesuai dengan otoritas pengetahuan, etika, estetika, adat istiadat, dan syariat agama. Adapun urgensi demokrasi dalam upaya pembentukan negara ideal, yang menurut Syahrur adalah negara "sekuler", yakni sebuah negara yang mendasarkan legitimasinya dari rakyat dan bukan dari para 
ahli agama serta sebuah negara yang tidak mengakui adanya Haman atau penjaga hukum-hukum Tuhan di negara tersebut adalah, selain dapat mengembangkan ilmu pengetahuan, demokrasi juga dapat meminimalisir potensi perpecahan sebab yang ditonjolkan dari demokrasi bukanlah semangat primordial, melainkan kepentingan bersama.

Kata Kunci: Demokrasi, Negara, Muhammad Syahrur, dan Islam

\section{Pendahuluan}

Dilektika Islam dan Barat masih tetap menjadi perbincangan yang menarik setidaknya bagi sebagian pemikir Islam sehingga tidaklah mengherankan apabila diskursus mengenai konsepsikonsepsi yang berasal dari Barat banyak menjadi perbincangan dalam dunia pemikiran Islam. Salah satu diskursus pemikiran yang cukup menyita perhatian kalangan pemikir Islam adalah mengenai demokrasi dan relevansinya dengan nilai-nilai yang terdapat dalam agama Islam. Permasalahan ini sebenarnya timbul berkenaan dengan ketertinggalan (umat) Islam dari Barat dalam hal peradaban dan ilmu pengetahuan atau dengan kata lain berkaitan dengan tradisi dan modernitas.

Dalam pemikiran Arab, semenjak pertengahan abad ke-19, yang merupakan periode renaissance (nahdah), telah berkembang pemikiran-pemikiran yang berupa pengakuan akan ketertinggalan dunia Arab dan Islam saat ini, terlebih jika dihadapkan dengan dunia Barat Modern. Para pemikir Islam terpolarisasi antara kesadaran akan keunggulan Barat, dan ketertarikan terhadap kejayaan Islam zaman klasik. ${ }^{1}$

Polarisasi pemikiran-pemikiran diatas sedikit banyak berpengaruh bagi timbulnya tiga tipologi pemikiran Arab kontemporer². Pertama, tipologi transformatif. Pemikiran mendasar dari kelompok pemikir dari tipologi ini adalah penolakan mereka

Muh. Tasrif, Nalar Politik Arab-Islam (Telaah Terhadap Pandangan Muhammad 'Abid al-Jabiri), Jurnal Dialogia, Jurnal Studi Islam dan Sosial, vol. 3 No. 2 Juli- Desember 2005, 69-70

2 A. Lutfi Assyaukani, Tipologi dan Wacana Pemikiran Arab Kontemporer, Jurnal Paramadina, vol. I, no. I, Juli-Desember 1998, 63-65 
atas pemikiran yang tidak berdasarkan kepada nalar kritis dan menganggap bahwa tradisi masa lalu sudah tidak relevan dengan tuntutan zaman sehingga harus dirubah. Salah seorang pemikir dari kelompok ini adalah Abdullah Laroui.

Yang kedua adalah tipologi reformistik. Jika pada kelompok yang pertama metode yang diajukan adalah transformasi sosial, pada kelompok ini proyek yang hendak digarap adalah reformasi dengan penafsiran-penafsiran baru yang lebih hidup dan lebih cocok dengan tuntutan zaman. Kelompok ini lebih spesifik lagi dibagi lagi ke dalam dua kecenderungan. Pertama, para pemikir yang menggunakan pendekatan rekonsruktif, yaitu melihat tradisi dengan perspektif pembangunan kembali. Maksudnya, agar tradisi suatu masyarakat (agama) tetap hidup dan bisa terus dapat diterima, maka ia harus dibangun kembali secara baru ( اعادة بنية من جديد) dengan kerangka modern dan prasarat rasional. Perspektif ini berbeda dengan kelompok tradisionalis yang lebih memprioritaskan metode "pernyataan ulang" atas tradisi masa lalu. Menurut yang terakhir ini, seluruh masalah umat Islam sebenarnya sudah pernah dibicarakan oleh para ulama dulu, karena itu, tugas kaum muslim sekarang hanyalah menyatakan kembali apa-apa yang pernah dikerjakan oleh pendahulu mereka. Pemikir dari kelompok reformis ini antara lain adalah antara lain Muhammad 'Abduh.

Kecenderungan kedua, dari tipologi pemikiran reformistik adalah penggunaan metode dekonstruktif. Metode dekonstruktif merupakan fenomena baru dalam pemikiran Arab Kontemporer. Para pemikir kelompok ini antara lain Muhammad Arkhoun.

Kelompok ketiga, adalah tipologi pemikiran ideal-totalistik. Ciri utama pemikiran dari kelompok ini adalah anggapan mereka akan sifat holistik dari Islam. Menurut paradigma ini, Islam adalah agama yang serba lengkap. lengkap dalam artian mencakup tatanan sosial, politik dan ekonomi. Sehingga mereka menolak unsur-unsur asing yang berasal dari barat dan mengajak untuk menghidupkan kembali nilai-nilai Islam yang pernah dipraktikkan 
oleh Nabi dan empat khalifahnya. Pemikir dari kelompok ini salah satunya adalah Muhammad Qutub. Yang mana dalam kamus intelektualnya hanya ada dua hal utama yang dia jadikan pedoman, yaitu Islam dan jahiliyah. ${ }^{3}$

Perbedaan pandangan dari tiga kecenderungan pemikiran diatas dapat dilihat misalnya masalah negara Islam. Sementara pemikir menyatakan bahwasanya Islam tidak mempunyai -atau paling tidak- tidak menetapkan suatu konsep baku yang harus diikuti oleh umat Islam mengenai konsep sebuah negara, melainkan bentuk sebuah negara tersebut diserahkan sepenuhnya kepada masyarakat yang bersangkutan dimana masyarakat itu berada. Islam hanya menetapkan nilai-nilai dasar yang harus ada dan dijunjung oleh suatu negara semisal keadilan dan lain sebagainya. Dan Islam tidak mempermasalahkan apakah negara tersebut berbentuk republik ataupun kerajaan, yang dilihat oleh Islam adalah apakah prinsip-prinsip Islam itu diterapkan atau tidak dalam sebuah negara tersebut. ${ }^{4}$

Sementara itu, terdapat sementara pemikir Islam yang menyatakan bahwa Islam telah mempunyai seperangkat aturanaturan yang bersifat menyeluruh dan terperinci dalam segala hal untuk mengatur kehidupan manusia, yang salah satunya adalah mengatur mengenai negara. Tidak seperti halnya kecenderungan pemikiran di atas, pemikir dari kelompok ini menyatakan bahwa Islam telah menetapkan konsep baku mengenai bentuk negara yang harus diikuti oleh umat Islam dimanapun dan kapanpun. Sehingga kelompok ini sampai pada kesimpulan bahwa jika umat Islam ingin bangkit dari keterpurukan yang telah dialami selama ini, maka umat Islam harus menerapkan hukum Islam secara kaffah di setiap lini kehidupan. Maka mengambil konsep atau bentuk

3 lbid, 82

4 Munawir Sadjzali, Islam dan Tata Negara Ajaran, Sejarah, dan Pemikiran, (Jakarta: Universitas Indonesia, 1990), 2. 
negara dari Barat adalah terlarang. Inilah sebagian pandangan dari kelompok ideal totalistik. ${ }^{5}$

Berbeda dari dua kecenderungan pemikiran di atas, terdapat pemikir Islam yang menyatakan bahwa antara Islam dan Negara adalah terpisah sama sekali. Yang mana -menurut mereka- tugas nabi adalah hanya pada wilayah nubuwwah saja dan tidak untuk membentuk sebuah Negara.

Adalah Muhammad Syahrur yang merupakan salah seorang diantara para pemikir Islam kontemporer yang meneriakkan perlunya pembaharuan dan peninjauan kembali pemikiran Islam. Ia sebagaimana tokoh-tokoh intelektual Islam kontemporer lainnya, mengajak untuk merenungkan dan memikirkan kembali Islam, karena Islam yang ada sekarang telah muncul dalam bentuk dan format yang demikian kaku, ekstrim, eksklusif dan terbelakang. ${ }^{6}$

Pola pemahaman skripturalis telah banyak mewarnai alam pemikiran umat, sehingga banyak umat menganggap hukum Islam harus diterapkan secara apa adanya tanpa harus melakukan analisis terhadap produk hukum yang telah dihasilkan oleh ulama zaman dulu agar lebih fleksibel dan lebih sesuai dengan tuntutan zaman. Upaya melegal-formalkan syari'ah adalah salah satu indikasi akan kecenderungan pemikiran skripturalis. Hukum Islam yang dihasilkan oleh ulama zaman klasik dianggap sebagai produk final yang apabila diterapkan akan dapat mengangkat derajat umat Islam dari kubangan keterbelakangan. Karenanya penggunaan teori-teori barat adalah satu perbuatan yang dilarang

5 Syari'at Islam menurut kelompok ini dianggap sebagia solusi bagi segala permasalahan yang dihadapi leh umat Islam. Masyarakat adil, makmur, sejahtera dan tenteram yang dicita-citakan oleh umat Islam akan dapat diwujudkan melalui penerapan syari'at Islam secara kaffah atau menyeluruh. Lebih lanjut penerapan syari'at Islam secara menyeluruh bagi kelompok ini dianggap sebagai bukti kehambaan kepada Allah dan bukti kecintaan kepada Rasul-Nya. Baca Hizbut Tahrir Indonesia, Waspadai Gerakan Anti Syari'ah, buletin Al-Islam, 3

${ }^{6}$ Muhammad Syahrur, Dialektika Kosmos dan Manusia, Dasar-Dasar Epistemology Qur'ani, terj. M. Firdaus, (Bandung: Nuansa, 2004), I I 
dalam agama bahkan haram. Karena sistem Barat (salah satunya demokrasi) adalah sistem kafir ${ }^{7}$

Jika pemikiran-pemikiran yang sangat eksklusif seperti disebutkan diatas terus berkembang maka umat akan mengalami kesulitan dalam menghadapi tantangan zaman yang setiap saat terus berkembang. Oleh karena itu, Syahrur berpendapat bahwa untuk mengatasi kekakuan pemikiran Islam yang telah mengendap dalam diri umat Islam hal yang harus dilakukan adalah dengan melepaskan diri dari kungkungan taqlid, baik pada wilayah akidah maupun pada wilayah $f i g h^{8}$.

Sudah saatnya umat Islam harus mengembangkan pemahaman tentang al-Qur'an dan sunah dengan model yang dapat mengantarkan umat Islam pada cara pandang abad modern. Artinya, menggunakan struktur pengetahuan yang berlaku pada abad modern ini dengan berpijak pada keyakinan akan kemampuan Islam untuk selalu bersifat relevan dengan segala konteks ruang dan waktu. Atau dengan kata lain umat Islam harus merombak cara pandangnya kepada al-Qur'an dan as-sunah agar dapat melampaui apa yang Syahrur sebut sebagai noda hitam umat Islam. ${ }^{9}$

Dengan mengungkapkan dua buah dalil dalam al-Qur'an.:

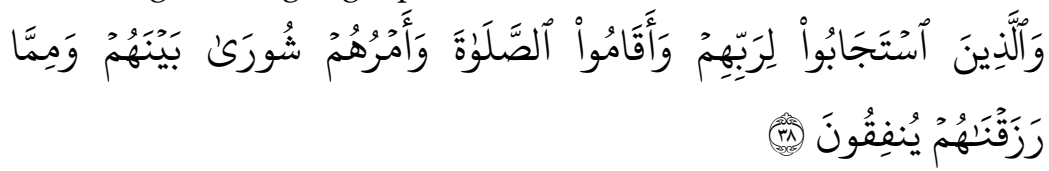

"Dan orang-orang yang menerima (mematuhi) seruan Tuhannya dan mendirikan shalat, sedang urusan mereka (diputuskan dengan musyawarah antara mereka dan mereka menafkahkan sebagian dari rezeki yang kami berikan kepada mereka (Q.S. as-Syura : 38$)^{10}$

\footnotetext{
7 Idris Thaha, Demokrasi Religius, Pemikiran Politik Nurcholis Madjid dan M. Amin Rais, (Jakarta: Teraju, 2004), 43-44

8 Muhammad Syahrur, Iman dan Islam : Aturan Aturan Pokok, (Yogyakarta: Jendela, 2002), xviii

9 Muhammad Syahrur, Tirani Islam Genealogi Masyarakat dan Negara, (Yogyakarta: LkiS, 1994), 180

${ }^{10}$ Departemen Agama, al-Qur'an dan Terjemahanya, (Bandung: PT. Syamil Cipta Media, 2005), 389
} 


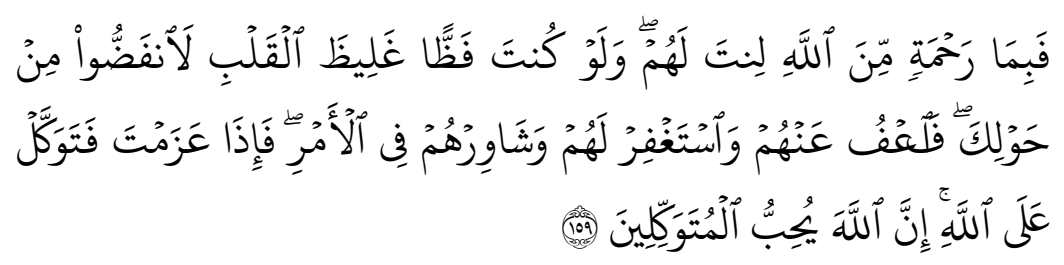

"Maka disebabkan rahmat dari Allah-lah kamu berlaku lemah lembut terhadap mereka. sekiranya kamu bersikap keras lagi berhati kasar, tentulah mereka menjauhkan diri dari sekelilingmu. Karena itu maafkanlah mereka, mohonkanlah ampun bagi mereka, dan bermusyawarahlah dengan mereka dalam urusan itu. Kemudian apabila kamu Telah membulatkan tekad, Maka bertawakkallah kepada Allah. Sesungguhnya Allah menyukai orang-orang yang bertawakkal kepada-Nya." (QS. Ali-Imran : 159) ${ }^{11}$

Dengan mendasarkan diri pada dua ayat di atas, Syahrur memaparkan salah satu idenya tentang demokrasi, Dalam pendapatnya syura harus dilihat dengan kacamata modern. Menurutnya demokrasi adalah representasi syura pada masa modern. Lebih lanjut dia berpendapat, berdasarkan dua ayat di atas, bahwa penolakan terhadap demokrasi adalah berarti menyalahi keimanan Islam.. ${ }^{12}$

Begitu pentingnya demokrasi bagi Syahrur, sehingga ia menyatakan bahwa negara yang ideal adalah negara demokrasi, sebab dengan demokrasi kebebasan berpendapat dijamin dan hubungan antara penguasa dengan rakyat dilakukan secara proporsional. Negara demokrasi inilah yang dia sebut sebagai negara yang meniscayakan kondisi moderat atau pertengahan bagi pola relasi antara penguasa dengan rakyat. ${ }^{13}$

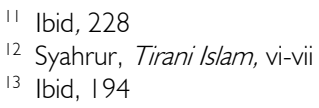


Keberanian Syahrur berpendapat demikian patut dipertanyakan mengingat demokrasi dan syura berangkat dari dua latar belakang yang berlainan secara historis. Demokrasi lahir di Yunani dan berkembang pesat di Eropa (utara), Sementara Islam Lahir di Arab dan berkembang pesat di wilayah selatan. Maka pertemuan Islam dan demokrasi adalah pertemuan peradaban, ideologi dan latar belakang sejarah yang jauh berbeda. ${ }^{14}$

Selain daripada itu demokrasi Barat adalah merupakan produk renaisance sejak abad ke-17 dan 18 M. Selama abad pertengahan, Barat mengalami pengalaman pahit dibawah kekuasaan raja-raja yang absolut. Ironisnya, sikap absolut tersebut tidak jarang didukung oleh gereja sebagai institusi keagamaan, sosial, politik dan ekonomi. Pada abad pertengahan gereja sangat mendominasi kehidupan masyarakat. Melihat kekuasaan gereja yang besar dan menyimpang sebagai perpanjangan tangan kekuasaan raja-raja, maka terjadilah pertentangan terhadap agama. Pada zaman renaisance pertentangan ini semakin meningkat. Orang-orang barat sudah mulai mempertanyakan keabsahan penafsiran gereja yang ternyata banyak yang tidak sejalan dengan ilmu pengetahuan. Disamping itu, mereka mengecam persekongkolan gereja dan raja-raja. Akhirnya, sejalan dengan meningkatnya pengetahuan orang-orang barat, mereka tidak lagi mempercayai agama. Manusialah yang berhak menentukan kehidupan mereka, tanpa boleh dicampuri oleh agama (kristen). Inilah awal terjadinya sekularisasi dalam masyarakat Barat. Demokrasi merupakan salah satu produk dari pertentangan orang-orang Barat dan agama. Karenanya, demokrasi tidak terlepas dari bias kehidupan masyarakat barat pasca renaisance yang sekular ${ }^{15}$.

${ }^{14}$ Eko Taranggono, Islam dan Demokrasi: Upaya Mencari Titik Temu. Jurnal al-Afkar, Edisi VI, tahun ke 5 : Juli-Desember 2002, 219

5 Mohammad Iqbal, Figh Siyasah Kontekstuali Doktrin Politik Islam, (Jakarta: Gaya Media Pratama, 200 I), 192-193 
Melihat dari kenyataan adanya perdebatan yang sengit antara yang pro dan yang kontra terhadap demokrasi dan kenyataan adanya ketersinggungan antara Islam dan konsep demokrasi (Barat) karya tulis ini diajukan selain untuk melihat lebih jauh konsep Muhammad Syahrur tentang demokrasi, juga dimaksudkan untuk melihat sejauhmana konsep demokrasi Syahrur tersebut dapat berperan dan mempunyai nilai penting dalam upaya pembentukan negara ideal. Yakni sebuah negara yang menurutnya adalah sebuah negara yang sebenarnya dikehendaki oleh Islam atau dengan bahasa lain adalah "negara Islam".

\section{Konsep Syura Menurut Pandangan Islam}

Kata syura berasal dari kata syawara, yang secara etimologis berarti mengeluarkan madu dari sarang lebah. Sejalan dengan pengertian ini, kata syura atau dalam bahasa Indonesia menjadi musyawarah mengandung makna segala sesuatu yang dapat diambil atau dikeluarkan dari yang lain (termasuk pendapat) untuk memperoleh kebaikan. Hal ini semakna dengan pengertian lebah yang mengeluarkan madu yang berguna bagi manusia. Dengan demikian, keputusan yang diambil berdasarkan musyawarah atau syura merupakan sesuatu yang baik dan berguna bagi kepentingan kehidupan manusia. ${ }^{16}$

Pendapat lain menyatakan bahwa kata syura berasal dari kata kerja syawara-yusyawiru yang berarti menjelaskan, menyatakan atau mengajukan dan mengambil sesuatu. Bentuk-bentuk lain yang berasal dari kata syawara adalah tasyawara, artinya berunding, saling bertukar pendapat, syawir yang artinya meminta pendapat atau musyawarah adalah saling menjelaskan dan merundingkan atau saling menerima dan menukar pendapat mengenai suatu perkara. Jadi kata syura dan jenisnya dalam bahasa arab diterjemahkan menjadi pemusyawaratan atau hal bermusyawarah

\footnotetext{
${ }^{16}$ Muhammad Iqbal, Fiqih Siyasah, Kontekstualisasi Doktrin Politik Islam, I 85
}

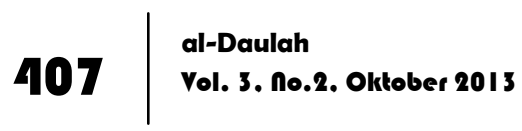


dalam bahasa Indonesia. Atau bisa juga dikatakan sebagai nasehat, konsultasi, perundingan, pikiran atau konsideran permufakatan. Syura juga bisa diartikan sebagai forum tukar menukar pikiran gagasan atau ide, termasuk saran-saran yang diajukan dalam memecahkan sesuatu masalah sebelum sampai kepada sebuah konklusi bagi keputusan-keputusan prinsip konstitusional. ${ }^{17}$

al-Qur'an menggunakan kata syura dalam tiga ayat. Pertama, surat al-Baqarah ayat 233, yang artinya:"Ibu-ibu itu menyusukan anak-anaknya dua tahun genap, bagi orang yang menghendaki menyempurnakan susuan. (Kewajiban) kewajiban atas bapak memberi belanja ibu anaknya itu dan pakaiannya secara ma'ruf. Tiadalah melarat ibu karena anaknya, dan tiadalah pula bapa melarat karena anaknya, dan terhadap warispun seperti demikian pula. Jika kedua ibu bapak hedak menceraikan anaknya dari menyusu (sebelum dua tahun) dengan kesukaan dan permusyawaratan antara keduanya, maka tiada berdosa keduanya. Jika kamu menghendaki perempuan lain menyusukan anakmu, maka tiada berdosa kamu bila kamu berikan upahnya secara ma'ruf. Takutlah kepada Allah dan ketahuilah bahwa Allah Maha Melihat apa yang kamu kerjakan" ( al-Baqarah ayat 233)18

Ayat di atas membicarakan kesepakatan atau musyawarah yang harus ditempuh suami istri jika mereka ingin menyapih anak sebelum dua tahun. Ini menunjukkan bahwa suami harus memutuskan permasalahan anak (termasuk masalah rumah tangga lainnya) dengan cara-cara musyawarah. Jangan ada pemaksaan kehendak dari satu pihak atas lainya.

Sedangkan ayat yang kedua yaitu surat Ali Imron 3:15 yang artinya: "Maka disebabkan rahmat dari Allah-lah kamu berlaku lemah lembut terhadap mereka. Sekiranya kamu bersikap keras lagi berhati kasar, tentulah mereka menjauhkan diri dari sekelilingmu. Karena itu maafkanlah mereka, mohonkanlah ampun bagi mereka, dan

\footnotetext{
17 M. Hasbi Amirudin, Konsep Negara Islam Menurut Fazlur Rahman, (Yogyakarta: UII Press, 2002), 124 dan Idris Thaha, Demokrasi Religius, Pemikiran Politik Nurcholis Madjid dan M. Amin Rais, 34

${ }^{18}$ Departemen Agama, al-Qur'an dan Terjemahanya, 29
} 
bermusyawarahlah dengan mereka dalam urusan itu. Kemudian apabila kamu Telah membulatkan tekad, Maka bertawakkallah kepada Allah. Sesungguhnya Allah menyukai orang-orang yang bertawakkal kepadaNya." (QS. Ali-Imran : 159)19

Ayat di atas turun berkenaan dengan peristiwa perang uhud yang membawa kekalahan umat Islam. Nabi sendiri mengalami luka-luka dalam perang tersebut. Ayat ini mengajarkan kepada Nabi dan tentunya kepada seluruh umat beliau, agar bermusyawarah dalam memutuskan sesuatu yang menyangkut kepentingan umat Islam.

Sedangkan ayat yang ketiga yaitu surat as-Syura 42:38, yang artinya: "Dan orang-orang yang menerima (mematuhi) seruan Tuhannya dan mendirikan shalat, sedang urusan mereka (diputuskan dengan musyawarah antara mereka dan mereka menafkahkan sebagian dari rezeki yang kami berikan kepada mereka (Q.S. as-Syura (42): 38)20

Dalam surat as-Syura tersebut Allah menggambarkan sifat orang mukmin yang salah satunya adalah mementingkan musyawarah dalam setiap persoalan yang mereka hadapi (wa amruhum syura bainahum).21

Di dalam syura terkandung beberapa prisip dasar yang merupakan prinsip-prinsip siyasah dalam kehidupan bermasyarakat dan bernegara ${ }^{22}$ sebagaimana yang terdapat dalam al-Qur'an, yakni.

a. Kebebasan berpikir (surat at-Tariq ayat 5, 6, 7)

b. Kebebasan berpendapat (surat an-Nisa' ayat 59 dan Ali Imron ayat 104)

c. Keadilan (surat an-Nisa' ayat 135 dan Surat al-Hadid ayat 25)

d. Persamaan (surat an-Nisa': 58)

\footnotetext{
${ }^{19}$ Ibid, 228

${ }^{20} \mathrm{lbid}, 389$

21 Muhammad Iqbal, Fiqih Siyasah, I85-186

22 Baca J. Suyuthi Pulungan, Fiqh siyasah, Ajaran Sejarah dan Pemikiran, (Jakarta: RajaGrafindo Persada, 1994), 1-16
} 
Musyawarah atau syura tersebut adalah merupakan pembahasan bersama dengan maksud untuk mencapai keputusan atau penyelesaian bersama. Mengingat pentingnya musyawarah, Islam tidak membatasi musyawarah hanya utntuk golongan dan lapisan tertentu. Ia dapat dilaksanakan oleh semua lapisan dan golongan masyarakat, dari golongan yang paling rendah sampai golongan yang paling tinggi, dari keluarga sampai Negara..$^{23}$

\section{Biografi Muhammad Syahrur}

Nama lengkap dari pemikir Islam liberal ini adalah Muhammad Syahrur Ibnu Dayb. Dilahirkan di Damaskus Syiria pada tanggal 11 April 1938, dari seorang ayah bernama Dayb ibnu Dayb dan seorang ibu yang bernama Siddiqah Binti Salih Filyun. Syahrur dikaruniai lima orang anak yaitu Tariq, al-Lais, Basul, Masun, dan Rima dengan seorang istri bernama 'azizah. ${ }^{24}$ Pendidikan dasar dan menengahnya dia tempuh di tanah kelahirannya, sampai memperoleh ijazah sekolah menengah pada tahun 1957 dari lembaga pendidikan Abdur Rahman al-Kawakibi, Damaskus. Pada tahun 1958 dia memperoleh beasiswa dari pemerintah dan berangkat ke Saratow di Moskow, Uni Soviet untuk mempelajari teknik sipil. Pendidikan teknik sipilnya ditempuh selama lima tahun, sampai dengan memperoleh gelar Diploma (1959-1964). Kemudian dia kembali ke negara asalnya dan mengajar pada Fakultas Teknik Sipil Universitas Damaskus (1965). ${ }^{25}$

Selanjutnya oleh Universitas dia dikirim ke Ireland National University, Irlandia yang kemudian mengantarkannya memperoleh gelar Magister (1969) dan Doktor (1972) dalam spesialisasi Mekanika Pertanahan dan Fondasi. Kemudian ia diangkat sebagai Profesor jurusan Teknik sipil di Universitas

${ }^{23}$ Atang Abd Hakim, Jaih Mubarok, Metodologi Studi Islam, (Bandung: Remaja Rosdakarya, 1999), 224

${ }^{24}$ Ahmad Syarqawi Ismail. Rekonstruksi Konsep Wahyu Muhammad Syahrur, (Yogyakarta: elSAQ, 2003), 43.

${ }^{25}$ Ibid, 44 
Damaskus (1972-1999)26 dan pada tahun 1982 -1983 Syahrur dikirimkan oleh Universitas tempat dia mengabdikan diri (Universitas Damaskus) untuk menjadi tenaga ahli pada al-Saud Consult di Arab Saudi. Selain itu bersama rekan-rekannya, dia membuka Biro Konsultan Teknik Dar al-Istisyarah al-Handasiyah di Damaskus.

Disamping penguasaanya terhadap bahasa Arab sebagai bahasa ibunya, tidak diragukan lagi dengan latar belakang pendidikanya di Uni Soviet, dia juga menguasai bahasa Inggris dan bahasa Rusia. ${ }^{27}$

Dalam merumuskan pemikiran-pemikiranya sehingga membentuk keyakinanya sebagai pemikir Islam liberal, Syahrur menapaki beberapa tahapan pemikiran yang biasa disebut sebagai fase-fase pemikiran. Fase-fase pemikirannya terbagi 3 (tiga), ${ }^{28}$ yaitu:

1. Fase Pertama (1970-1980)

Permulaan dari fase pemikiran Syahrur ini adalah ketika ia menempuh pendidikan pada jenjang Magister dan Doktor dalam bidang Teknik Sipil di Universitas Nasional Irlandia. Fase ini bisa dikatakan sebagai fase kontemplasi atau perenungan, kemudian berlanjut pada peletakan dasar-dasar pemikiranya tentang az-zikr. Namun diakui oleh Syahrur bahwa pada fase ini masih belum menghasilkan pemikiran yang menurutnya matang dan komprehensif, dikarenakan masih adanya kecenderungan untuk terjebak kepada pengaruh pemikiran-pemikiran klasik dan juga pada khasanah pemikiran modern, disamping juga dia merasa masih dipengaruhi oleh pemikiran-pemikiran teologis yang tertuang dalam bentuk aliran kalam maupun figh mazhab. Dalam kurun waktu 10 tahun (1970-1980) tersebut Syahrur mendapati

\footnotetext{
${ }^{26}$ Andreas Chrismann, Bentuk Teks (Wahyu) Tetap, Tetapi Kandungannya Selalu Berubah: Tekstualitas dan Penafsirannya dalam al-Kitab Wa al-Qur'an, Pengantar dalam Muhammad Syahrur, Metodologi Fiqh Islam Kontemporer, (Yogyakarta: elSAQ Press, 2004), 19

${ }_{27}$ M. Aunul Abied (ed), Islam Garda Depan Mosaik Pemikiran Islam Timur Tengah, (Bandung: Mizan, 200 I), 237

${ }^{28}$ M. Syahrur, Iman dan Islam : Aturan-Aturan Pokok, xviii-xv
}

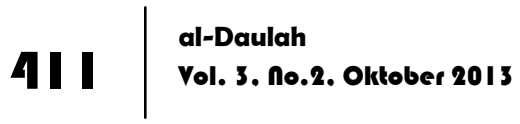


bahwa dasar-dasar ajaran agama yang diterima umat Islam selama ini ternyata bukan merupakan dasar-dasar ajaran agama yang sebenarnya. Dikarenakan, menurut Syahrur, tidak bisa menjawab tantangan Zaman. ${ }^{29}$

Ketimpangan yang dialami oleh umat Islam dalam masalah dasar-dasar agama tersebut paling tidak dikarenakan oleh dua hal, yaitu yang pertama, ajaran tentang aqidah Islam yang diajarkan kepada umat di lembaga-lembaga pendidikan bercorak $m u^{\prime}$ tazili ataupun juga lebih bercorak asy'ari. Sedangkan yang kedua adalah dikarenakan ajaran-ajaran figh yang diterima merupakan hasil dari taqlid terhadap para imam figh seperti Imam Maliki, Imam Abu Hanifah, Imam Ahmad bin Hambal, Imam Syafi'i, ataupun Ja'fari. Menurutnya jika kita ingin menampilkan bentuk Islam yang murni, maka kita harus dapat melepaskan diri dari kungkungan pemikiran pemikiran produk taqlid dan menggunakan kerangka pemikiran modern untuk melakukan analisa terhadap Islam. Hal ini dikarenakan apabila penelitian modern dan ilmiyah masih terkungkung dalam kedua hal diatas maka studi Islam pada hakikatnya berada pada titik yang rawan dan riskan. ${ }^{30}$

\section{Fase Kedua (1980-1986)}

Pertemuan Syahrur dengan salah seorang teman lamanya yang sedang mendalami studi tentang bahasa di Uni Soviet, DR. Ja'far Dik al-Bab, telah memberikan kesempatan kepadanya untuk labih intens dalam pembacaan kontemporernya pada al-Qur'an. Melalui teman lamanya tersebut, Ia dapat menyampaikan tentang perhatian besarnya yang dalam kepada al-Qur'an, filsafat dan tentang studi bahasa. Sehingga akhirnya Ia dapat berkenalan dengan pandangan-pandangan ahli-ahli bahasa seperti al-Farra', Abu Ali al-Farisi, Ibnu Jinni dan al-Jurhani. Perkenalannya dengan pemikiran-pemikiran dari ahli-ahli bahasa tersebut telah membawanya pada kesimpulan bahwa satu kata mempunyai satu makna dan bahasa arab adalah bahasa yang didalamnya tidak

\footnotetext{
${ }^{29}$ Ibid, xiv

${ }^{30}$ lbid, xiv
} 
terdapat sinonimitas. Sehingga akhirnya dia mulai melakukan analisa-analisa terhadap terma-terma yang terdapat dalam alQur'an dengan menggunakan kerangka pemikirannya yang digali dari pengetahuannya tentang bahasa sebagaimana yang telah disebutkan di atas, bersama Ja'far.

\section{Fase Ketiga (1986-1990)}

Pada Fase ini, Syahrur mulai lebih memfokuskan diri untuk menyusun pemikiran dalam topik-topik tertentu. Sehingga dia berhasil menyelesaikan bab tersulit dari bukunya yang fenomenal, al-Kitab wa al-Qur'an pada tahun 1987 awal.

\section{Latar Belakang Pemikiran Muhammad Syahrur}

Jika diperhatikan dari latar belakang pendidikannya, pada mulanya Syahrur memang tidak bersentuhan-atau paling tidak mendalami secara intensif-dengan keilmuan Islam. Perhatiannya yang dalam pada kajian ilmu-ilmu keislaman sebenarnya baru dimulai ketika ia mengambil jenjang Magister dan Doktor di Dublin Irlandia pada tahun 1970-1980. Pada bentangan tahun ini ia mulai mencoba mengadakan kajian ulang (al-Muraja'ah) terhadap konsep-konsep yang sudah dianggap hal baku dalam doktrin teologi Islam. ${ }^{31}$

Menurut pemahaman Syahrur apa yang dianggap sebagai konsep yang baku dan kebenaran yang diyakini oleh umat Islam sekarang ini adalah konsep-konsep yang diterima begitu saja yang sebenarnya harus dikaji ulang. Yang mana dia sebut sebagai kebenaran-kebenaran yang terbalik, sebagaimana sebuah lukisan yang digambar dari pantulan kaca cermin. Semuanya terkesan benar padahal pada hakikatnya adalah salah. ${ }^{32}$

Paradigma dasar yang dijadikan sebagai prinsip oleh umat Islam yaitu bahwa Islam adalah agama yang bersifat holistik, yang berarti Islam mampu menjawab segala tantangan zaman serta

\footnotetext{
31 A.Rafiq Zainul Mun'im, Metodologi Penafsiran Kontemporer Muhammad Syahrur, Jurnal Akademika Vol 18 No. 2. Maret 2006, 170.

${ }^{32}$ Achmad Syarqawi Ismail, Rekonstruksi, 45.
} 
bersifat universal yang melampaui batas ruang dan waktu atau bahkan melewati sekat-sekat kemanusiaan. Kepercayaan diri yang terlalu tinggi akan universalitas Islam inilah yang kemudian menancap dalam keyakinan teologis umat Islam. Bahwa mereka akan selalu menjadi yang pertama dan terdepan dalam segala bidang kehidupan.

Stetemen teologis akan keunggulan Islam ini sebenarnya bukan mengajak umat untuk mengembangkan fatalisme, yakni untuk berpangku tangan sambil berkeyakinan menjadi umat yang mulia. Melainkan menyiratkan sebuah hakikat yang sebenarnya merupakan sebuah jargon yang mesti menjadi cambuk bagi umat Islam untuk selalu berusaha mengaktualisasikan diri dalam situasi, kondisi dan waktu apapun, kapanpun dan dimanapun. Universalitas ini juga menyiratkan sebuah ajaran yang menyeluruh dalam segala lini kehidupan. Hal inilah yang sebenarnya ingin dibangun dan diciptakan oleh ajaran teologis ini untuk kemudian dijadikan pegangan oleh umat Islam atau dalam kata lain umat Islam harus selalu mengedepankan dialogis kontekstual. ${ }^{33}$

Namun ibarat api jauh dari panggang, idealisme tinggi yang dibawa Islam tidak menemukan basis realisasinya pada tatanan realitas dikarenakan sikap lengah yang ditunjukkan oleh umat Islam. Sehingga realitas yang pahit harus ditelan oleh umat, dimana umat Islam selalu menjadi umat yang terbelakang dalam berbagai bidang dibandingkan dengan kemajuan yang dicapai oleh umat lain. Tidak hanya pada wilayah politik, pada bidang ekonomi dan teknologi pun kondisi umat Islam sangat memprihatinkan. ${ }^{34}$ Secara politis umat Islam sering kali menjadi bulan-bulanan berbagai wacana yang dilontarkan barat, umat Islam dianggap sebagai simbol kemunduran dan ladang subur tersemainya terorisme yang mengancam eksistensi kedamaian dunia. Sebegitu menakutkannya sehingga mungkin bisa

${ }^{33}$ M.Syahrur, Dialektika Kosmos dan Manusia,Dasar-Dasar Epistemology Qur'ani, 9

${ }^{34}$ Ibid, 10 
disejajarakan dengan ketakutan barat ataupun dunia akan bahaya nuklir yang mengancam. Dalam posisi yang termarginalkan pada ranah politik seperti ini adalah sangat sulit bagi umat Islam untuk membalik wacana dan menempatkan diri pada posisi yang dominan.

Belum lagi pada wilayah ekonomi, ternyata umat Islam hanya menempati posisi sebagai penonton dan objek, dalam artian hanya sebagai konsumen. Karena memang harus diakui bahwa pemegang kekuasaan perekonomian dunia adalah orang-orang non Muslim, yakni orang-orang yang pada hakikatnya adalah umat yang tidak pernah melekatkan diri kepada Islam.

Tidak jauh berbeda dengan wilayah politik dan ekonomi, ternyata dalam bidang sains dan teknologi pun umat Islam berada jauh di belakang kemajuan peradaban barat. Dimana untuk memenuhi kebutuhannya, umat Islam lebih banyak menggantungkan diri pada negara-negara (umat) non Muslim.

Kekalahan Arab atas Israel pada tahun 1967 membangkitkan kritikan pedas terhadap seluruh pemikiran Islam dan Arab tradisional, dan sekaligus memicu perkembangan pendekatan analisis kritis terhadapnya. ${ }^{35}$

Tahun 1967 dianggap sebagai starting poin bagi perubahan cara pandang bangsa Arab terhadap problem sosial budaya yang dihadapinya. Dan langkah pertama yang dilakukan oleh para pemikir Arab-Islam adalah dengan melakukan analisa dan menjelaskan mengenai sebab-sebab kekalahan tersebut. Sehingga akhirnya mereka sampai ada sebuah hipotesa bahwa yang menjadi penyebab dari kekalahan tersebut adalah masalah cara pandang orang Arab-Islam kepada budayanya sendiri dan kepada pencapaian kemajuan atau kemoderenan. ${ }^{36}$

\footnotetext{
35 Muhammad Syahrur, Dasar dan Prinsip Hermeneutika al-Quran Kontemporer, (Yogyakarta: elSAQ Press, 2007), 5

${ }^{36}$ A. Lutfi Assyaukani, Tipologi dan Wacana Pemikiran Arab Kontemporer. Jurnal Paramadina, vol. I, no. I, Juli-Desember 1998, 6I-62
} 
Melihat realitas semacam ini, Syahrur menawarkan sebuah jawaban atas problem tersebut. Meskipun dia sependapat dengan para sarjana al-Qur'an tentang keharusan kembali kepada alQur'an dalam menyelesaikan problem umat Islam, namun berbeda dengan para ahli al-Qur'an tersebut, dia menyerukan untuk melampaui tradisi secara ekstrim dan mengajak umat untuk memahami al-Qur'an seolah-olah Nabi Muhammad baru saja meninggal. ${ }^{37}$

Menurut Syahrur, letak kesalahannya adalah dalam kerangka pikir dan logika yang digunakan oleh umat Islam dalam memahami teks al-Qur'an. Ia berpendapat jika kita mengandaikan Islam yang dibawa oleh Nabi Muhammad SAW adalah ajaran yang bersifat universal, maka ia harus mempunyai tingkat dinamisasi yang tinggi dalam merespon realitas yang dihadapi. Ketika teks tersebut dipahami menggunakan kerangka logika yang deduktif - linier, dalam artian bahwa apa yang sudah ada dalam konstruksi Islam yang kita temui sekarang harus bisa diterapkan dalam konteks apapun, maka yang terjadi sesungguhnya adalah pemaksaan sesuatu yang tetap (statis) kepada sesuatu yang selalu berubah. ${ }^{38}$

37 Syahrur, Dasar dan Prinsip Hermeneutika, 9. Syahrur melihat bahwa pemikiran Islam kontemporer memiliki problem-problem mendasar yaitu (I) tidak adanya metode penelitian ilmiyah yang objektif, khususnya terkait dengan kajian nash yang diwahyukan kepada Muhammad (2) kajian-kajian keislaman yang ada seringkali berpijak atau bertolak dari perspektifperspektif lama yang dianggap sudah mapan, yang terperangkap pada kungkungan subjektif, bukan objektifitas. Kajian-kajian itu tidak menghasilkan sesuatu yang baru, melainkan hanya memperkuat asumsi yang dianutnya (3) tidak dimanfaatkannya filsafat humaniora, lantaran umat Islam selama ini masih mencurigai pemikiran Yunani (barat) sebagai keliru dan sesat. (4) tidak adanya epistemologi Islam yang falid. Hal ini berdampak pada fatalisme dan indoktrinasi mazhab-mazhab yang merupakan akumulasi pemikiran-pemikiran abad-abad silam, sehingga pemikiran Islam menjadi sempit dan tidak berkembang (5) produk-produk fiqih yang ada sekarang sudah tidak relevan lagi denagan tuntutan modernitas. Yang diperlukan adalah formulasi fiqih baru. Lihat http://www. islamemansipatoris.com

38 Syahrur, Dialektika Kosmos., II. Syahrur begitu bersikeras bahwa tiap-tiap generasi mampu memberikan interpretasi al-Qur'an yang memancar dari realitas yang muncul dan sesuai dengan kondisi dimana mereka hidup. Hasil interpretasi al-Qur'an generasi awal tidaklah mengikat masyarakat muslim modern. Bahkan lebih jauh ia berpendapat bahwa kesalahan utama fiqh Islam dan figh Islam konfensional sekarang ini bersumber dari kesalahan metodologi yang tidak memperhatikan karakteristik dan fleksibilitas pengertian teks-teks kitab suci, sehingga 


\section{Konsep Demokrasi Muhammad Syahrur}

\section{Definisi Demokrasi}

Sebelum melakukan kajian terhadap konsep demokrasi Syahrur, hal utama yang harus dipahami adalah bahwa hubungan Islam dan demokrasi dapat dilihat dalam dua pendekatan yaitu normatif dan empiris. Secara normatif berarti mempersoalkan nilai-nilai demokrasi dari sudut pandang Islam. Sedangkan secara empiris berarti melakukan analisa implementasi demokrasi dalam praktek politik dan ketatanegaraan. ${ }^{39}$ Berangkat dari dua asumsi dasar di atas, penulis mencoba melihat konsepsi Syahrur tentang demokrasi dari sudut pandang Islam dan praktik ketatanegaraan pada masa Nabi dan Khulafaur Rasyidin.

Menurut konsep Syahrur, demokrasi adalah praktik kebebasan yang dilakukan sekelompok manusia sesuai dengan otoritas pengetahuan, etika, adat-istiadat dan syari'at agama. ${ }^{40}$ Dia meyakini bahwa demokrasi adalah representasi syura pada masa modern, dengan berpijak pada kenyataan bahwa demokrasi mengakui kebebasan dan dengan dasar argumentasi bahwa syura mempunyai segi nilai dan segi teknis. ${ }^{41}$ Jadi dapat dipahami bahwa selain memperoleh legitimasi teologis, demokrasi juga merupakan sistem yang memungkinkan adanya pewarnaan yang berbeda sesuai dengan kearifan lokal di mana sistem tersebut dipraktikkan. Selain itu dengan mengungkapkan relevansi syura dengan demokrasi terlihat adanya usaha Syahrur untuk menunjukkan kepada umat Islam bahwa demokrasi tidak selalu identik dengan Barat.

membebani punggung umat dan tidak sesuai lagi dengan perkembangan ilmu pengetahuan serta kondisi dan situasi abad ke-20. Dia yakin bahwa muslim modern, karena kemajuan budaya dan ilmu pengetahuan mempunyai perangkat pemahaman metodologis yang lebih baik dibandingkan para pendahulunya (abad ke-7 M) dalam memahami pesan-pesan Allah yang disampaikan kepada Rasul-Nya. Lihat http://www. islamemansipatoris.com

39 M. Syafi'i Ma'arif, Islam Politik dan Demokrasi di Indonesia, dalam Bosco Carvallo dan Dasrizal, Aspirasi Umat Islam Indonesia, (Jakarta: Lappenas, 1983), 47-55.

40 Muhammad Syahrur, Tirani Islam Genealogi Masyarakat dan Negara, 180

$4 I$ M. Syahrur, Metodologi Figh Islam Kontemporer, (Yogyakarta: elSAQ Press, 20 I 0), 308

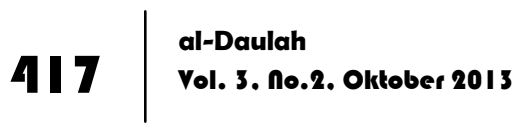


Pendapat Syahrur bahwa demokrasi merupakan representasi konsep syura dalam al-Qur'an, dapat ditelaah dari makna kata syura itu sendiri. Apabila dilihat dari akar kata-nya, kata syura berasal dari kata kerja syawara-yusyawiru yang berarti menjelaskan, menyatakan atau mengajukan dan mengambil sesuatu. Bentukbentuk lain yang berasal dari kata syawara adalah tasyawara, artinya berunding, saling bertukar pendapat, syawir yang artinya meminta pendapat atau musyawarah adalah saling menjelaskan dan merundingkan atau saling menerima dan menukar pendapat mengenai suatu perkara. Jadi kata syura dan jenisnya dalam bahasa arab diterjemahkan menjadi pemusyawaratan atau hal bermusyawarah dalam bahasa Indonesia. Atau bisa juga dikatakan sebagai nasehat, konsultasi, perundingan, pikiran atau konsideran permufakatan. Syura juga bisa diartikan sebagai forum tukar menukar pikiran gagasan atau ide, termasuk saran-saran yang diajukan dalam memecahkan sesuatu masalah sebelum sampai kepada sebuah konklusi bagi keputusan-keputusan prinsip konstitusional. ${ }^{42}$ Mengingat, ayat yang berbicara mengenai syura (musyawarah) sangatlah sedikit dan itupun hanya bersifat sangat umum dan global. al-Qur'an memang tidak membicarakan hal ini lebih jauh dan detail. Kalau dilihat secara mendalam, hikmahnya tentu besar sekali. al-Qur'an hanya memberikan seperangkat nilainilai yang bersifat universal yang harus diikuti umat Islam. Sementara masalah cara, sistem, bentuk, dan hal-hal lainnya yang bersifat teknis diserahkan sepenuhnya kepada manusia sesuai dengan kebutuhan mereka dan tantangan yang mereka hadapi. Aplikasi musyawarah merupakan bidang atau lingkup atau wilayah ijtihad manusia. ${ }^{43} \mathrm{Jadi}$, al-Qur'an menganut prinsip bahwa untuk masalah-masalah yang bisa berkembang sesuai dengan kondisi sosial, budaya, ekonomi, dan politik umat Islam, maka al-

${ }^{42}$ M. Hasbi Amirudin, Konsep Negara Islam Menurut Fazlur Rahman, 124 dan Idris Thaha, Demokrasi Religius, Pemikiran Politik Nurcholis Madjid dan M. Amin Rais, 34

${ }^{43}$ Muhammad Tahir Azhari, Negara Hukum, Suatu Studi tentang Prinsip-Prinsipnya Dilihat dari Segi Hukum Islam, Implementasinya Pada Periode Negara Madinah dan Masa Kini, Jakarta: Kencana, 2004), 85. 
Qur'an hanya menetapkan garis-garis besarnya saja. Seandainya masalah musyawarah ini dijelaskan al-Qur'an secara rinci, besar kemungkinan umat Islam akan mengalami kesulitan ketika berhadapan dengan realitas sosial yang berkembang. Umat Islam terpaku pada teks-teks ayat al-Qur'an saja tanpa berani melakukan improvisasi. oleh sebab itu dengan memberi garis besar saja, Allah Swt memberikan kebebasan sepenuhnya kepada umat Islam untuk menggunakan akal dan pikiran mereka, sejauh tidak melanggar batasan-batasan yang ditentukannya dalam al-Qur'an. Agar prinsip syura ini dapat berjalan dengan baik, sesuai dengan yang ditentukan Allah Swt setidaknya musyawarah yang dilakukan harus mempertimbangkan tiga hal, yaitu; masalah apa saja yang menjadi lapangan musyawarah, dengan siapa musyawarah dilakukan serta bagaimana etika dan cara musyawarah dilakukan. ${ }^{44}$

Menurut tradisi demokrasi Barat, sejarah demokrasi bermula pada masa sistem kota Yunani dan pada karya Aristoteles. ${ }^{45}$ Untuk beberapa hal, demokrasi Yunani dan konsep-konsep Aristoteles pada bagian-bagian tertentu berbeda dengan demokrasi modern. Demokrasi Yunani bersumber pada partisipasi rakyat terhadap masalah-masalah pemerintahan yang langsung sedang demokrasi modern berdasar pada perwakilan. Penyebab dari kenyataan ini adalah dikarenakan jumlah penduduk pada masa dahulu dengan masa sekarang adalah berbeda, selain karena faktor kemudahan. Meskipun pada masa modern dikenal adanya referendum atau penentuan keinginan rakyat melalui penyertaan dan partisipasi seluruh rakyat dalam referendum tersebut.

Hal diatas menunjukkan bahwa sebenarnya sejak semula penerapan demokrasi itu tidaklah mengikuti pola yang baku. Atau dengan kata lain tidak ada sebuah keharusan konsep demokrasi dari suatu negara diterapkan di negara yang lain. Melainkan

\footnotetext{
44 Muhammad lqbal, Fiqih Siyasah Kontekstuali Doktrin Politik Islam, 186

45 Muhammad A. al-Buraey. Islam Landasan Alternatif Administrasi Pembangunan, terj. Achmad Nashir Budiman, (Jakarta: Rajawali, 1986), 92
}

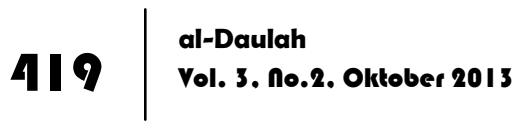


semuanya itu diterapkan dengan berdasarkan pada kondisi realitas dimana sistem tersebut diterapkan. Hal ini menunjukkan bahwa dimensi tempat dan waktu memberi warna beragam antara pelaksanaan prinsip-prinsip demokrasi di satu situasi dan kondisi sosial budaya dan lainya. Meskipun demikian ada norma yang bisa dikatakan baku yang harus ada dimana saja dan kapan saja, supaya, ia mencerminkan semangat demokrasi itu, yang salah satunya adalah prinsip "pertanggung-jawaban kepada rakyat". 46 Pandangan ini bersesuaian dengan pendapat Syahrur bahwa demokrasi adalah berdialektika dengan realitas, yang dibuktikan dengan definisinya bahwa demokrasi adalah praktik kebebasan yang dilakukan sekelompok manusia sesuai dengan otoritas pengetahuan, etika, adat-istiadat dan syari'at agama sebagaimana yang penulis sebutkan terdahulu.

Pada dasarnya syura merupakan gagasan politik utama dalam al-Qur'an dan konsep syura ini apabila ditransformasikan pada kehidupan modern maka sistem politik demokrasi adalah lebih dekat dengan ciri-ciri politik Qur'ani. Kritik dalam demokrasi bukanlah dari aspek normatifnya tetapi dalam praktik pelaksanaanya yang kadangkala justru bertentangan dari konsep ideal demokrasi itu sendiri. Dari aspek praktik, demokrasi bukannya tanpa cacat. Dimana demokrasi bisa memberikan peluang kepada para calon pemimpin untuk mengumbar janji, dimana orang yang paling pandai membual, maka dialah yang akan menjadi pilihan dari rakyat dalam kampanye pemilihan umum dan akhirnya menjadi penguasa. Namun dengan cacatnya itu tidak ada alasan bagi umat Islam untuk menolak demokrasi. Karena pada hakikatnya prinsip tauhid dalam Islam berisi persamaan, solidaritas dan kebebasan. ${ }^{47} \mathrm{Jika}$ perbedaan telah menjadi sebuah kenyataan dalam sebuah komunitas manusia,

\footnotetext{
46 Frans Magnis Suseno, Demokrasi dan Agama dalam Soetjipto Wirosardjono, Dialog dengan Kekuasaan, Esai-Esai Tentang Agama, Negara dan Rakyat, (Bandung: Mizan, 1995), 183-185

47 M. Syafili Anwar, Pemikiran dan Aksi Islam Indonesia: Sebuah Kajian Politik tentang Cendekiawan Muslim Orde Baru, (Jakarta: Paramadina, 1995), 223
} 
maka kebutuhan yang niscaya segera muncul bukanlah meredam dan menyembunyikan atau bahkan mengedepankan upaya represif untuk meredam adanya pluralitas tersebut, melainkan memberikan ruang terbuka yang memberikan kesempatan yang seluas-luasnya bagi penyaluran aspirasi yang berbeda tersebut, agar perbedaan tersebut berdialektika dengan sehat dan dialektika itu hanya dapat terwadahi oleh sistem yang bernama demokrasi. Demokrasi bukan saja siap menghadapi dan mewadahi perbedaan, melainkan konsep ini bahkan menjadikan perbedaan sebagai hal utama yang menjadi bahan bakunya. Demokrasi memerlukan adanya perbedaan aspirasi dan kepentingan untuk dirujukkan, sehingga berkembang menjadi aspirasi yang semakin berkualitas. ${ }^{48}$ Kenyataan ini sekaligus meligitimasi pendapat Syahrur bahwa demokrasi mampu mencegah terjadinya ledakan konflik sosial dalam masyarakat yang majemuk.

\section{Rujukan-Rujukan Demokrasi}

Demokrasi yang ingin diterapkan Oleh Syahrur adalah apa yang biasa disebut sebagai demokrasi religius. Dengan melihat dasar rujukan bagi demokrasi dengan memasukkan unsur syariat agama, yang dalam hal ini adalah Islam, menyatakan bahwa demokrasi yang ingin diterapkanya bukanlah merupakan peniruan dari konsep yang telah dipraktekkan di Barat. Dimana karena demokrasi ini, kemudian bisa menjadikan minuman keras yang semula dilarang, kemudian menjadi sesuatu yang legal. ${ }^{49}$

\footnotetext{
${ }^{48}$ Adhyaksa Dault, Islam dan Nasionalisme, Reposisi Wacana Universal dalam Konteks Nasional, (t.tp: Pustaka al-Kautsar, 2005), 90

49 Amerika membuat suatu hukum dan kemudian membatalkan hukum yang dibuat dan disetujui itu, yaitu The Prohition Law of America. Mula-mula rakyat Amerika secara rasional dan logis berpendaat bahwa minum-minuman keras tidak saja merusak kesehatan, tetapi juga menimbulkan dampak negatif bagi kemampuan mental dan intelektual manusia serta mendorong timbulnya kekacauan dalam masyarakat. Rakyat Amerika menerima kenyataan ini dan menyetujui diberlakukanya The Prohibition Law of America hukum ini disetujui dengan suara mayoritas. Akan tetapi ketika hukum ini mulai diberlakukanya secara sungguh-sungguh, rakyat yang mula-mula menyetujuinya kemudian memberontak tidak mau menerima. Akhirnya dengan kehendak rakyat pula hukum itu dicabut. Rakyat yang sama, yang mula-mula menyetujui hukum itulah yang kemudian mencabutnya sendiri. Baca Amin Rais, pengantar dalam buku al-
}

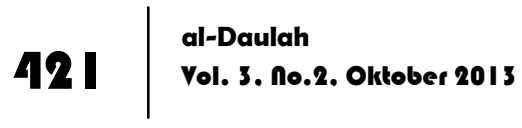


Dimana hal-hal yang diharamkan oleh Allah adalah tidak tunduk kepada voting atau pendapat ${ }^{50}$.

Adanya prinsip kebebasan berpikir dalam demokrasi sebagaimana yang diungkapkan Syahrur, ${ }^{51}$ merupakan prinsip dasar yang terdapat dalam Islam, yang merupakan hak-hak individu yakni sesuai dengan syariat Islam, kebebasan berpikir merupakan piranti untuk membebaskan akal dari takhayul, tradisi yang tidak sehat atau kebebasan-kebebasan yang tidak masuk akal. Hal ini merangsang setiap pribadi untuk memikirkan segala sesuatu dari kehidupan sehari-harinya, menganalisa, menimbangnimbangnya dengan pilihan (alternatif) yang ada dan kemudian memilih yang paling sesuai dengan akal..$^{52}$

Syahrur terlihat begitu antusias menunjukkan bahwa pada dasarnya konsep demokrasi adalah merupakan suatu sistem yang Islami karena sejalan dengan konsep syura dalam Islam. Selain itu, dia juga memberi pemahaman bahwa tidak ada yang perlu ditakutkan dalam demokrasi, sebab demokrasi tidak bisa dilihat dengan satu kaca mata saja. Artinya demokrasi tidak hanya didasarkan pada teori Barat. Hal ini sekaligus menepis asumsi yang menyatakan bahwa demokrasi adalah sistem barat yang kafir dan harus dijauhi bahkan dilarang dipraktekkan oleh orang Islam. ${ }^{53}$

Namun yang patut dicermati dari pendapatnya adalah bahwa orang yang menolak demokrasi dan kebebasan berarti telah menyalahi keimanan Islam. ${ }^{54}$ Dengan mendasarkan argumentasinya pada dua buah ayat al-Qur'an yang membicarakan tentang syura yaitu QS. Ali-Imran : 159 dan Q.S. asSyura (42): 38, sepertinya Syahrur telah terjebak pada uforia

Maududi, Khilafah dan Kerajaan: Evaluasi Kritis Atas Sejarah Pemerintahan Islam, (Bandung: Mizan, 1998), 26-28

50 Muhammad Syahrur, Metodologi Fiqih Islam Kontemporer, 312

5) Syahrur, Metodologi Figh, 304

52 Muhammad A. al-Buraey, Islam Landasan Alternatif Administasi Pembangunan, 82-89

${ }^{53}$ Idris Thaha., Demokrasi Religius, Pemikiran Politik Nurcholis Madjid dan M. Amin Rais, 43-44

${ }^{54}$ Syahrur, Tirani Islam vi-vii 
demokrasi dengan hanya melihat demokrasi pada tataran nilainilai dan konsep-konsep ideal yang ada dalam demokrasi, dengan sedikit "adaptasi" yang berupa pemasukan unsur agama dalam teorinya. Antusiasme Syahrur yang begitu besar terhadap demokrasi ini, sebenarnya patut ditelaah dengan melihat latar belakang kehidupanya, selain latar belakang pendidikan juga latar belakang sosial politik yang melingkupinya, mengingat seorang pemikir tidak akan dapat melepaskan diri dari kondisi objektif yang melingkupinya ketika merumuskan teorinya tentang sesuatu atau dengan kata lain pemikir tidaklah hidup di ruang hampa. Jika ditelaah lebih lanjut dari latar belakang kehidupannya yang banyak diwarnai keprihatinan akan kemunduran yang dialami umat Islam, yang menurut pengakuannya "pembacaan kontemporernya"55 itu mulai dilakukan ketika menempuh pendidikan di Uni Soviet. Dalam keyakinannya salah satu sebab dari kemunduran umat itu dikarenakan kesalahan dalam melakukan pembacaan terhadap konsepsi yang terdapat dalam ajaran agama, maka hal yang harus dilakukan adalah dengan melakukan pembacaan ulang terhadap ajaran agama dan turas dengan kaca mata modern atau yang dalam pandanganya adalah dengan menggunakan teori ilmiah modern. Ketika pembacaan kontemporer yang dilakukannya mendapat tantangan yang begitu hebat baik dari kalangan penguasa, yang ditandai dengan dilakukanya pencekalan atau pelarangan terhadap buku karya Syahrur di beberapa negara di Timur Tengah, juga dilakukan oleh para intelektual dan otorita ulama yang telah menganggap pendapatnya atau karya tulisnya sebagai karya yang berbahaya,

55 Pembacaan kontemporer disini dimaksudkan sebagai suatu metode untuk memahami atau menelaah ajaran agama (al-Qur'an) dengan tidak mengikatkan diri pada kasanah keilmuan klasik, yang menurut Syahrur berarti melakukan pembacaan atau telaah terhadap al-Qur'an dengan menggunakan seperangkat pengetahuan modern dan meningggalkan hasil keilmuan klasik yang sudah usang dengan mendasarkan diri pada keyakinan bahwa umat Islam harus melakukan kajian keagamaan dengan menganggap seolah-olah Rasulullah baru saja meninggal. Muhammad Syahrur, Islam dan Konferensi dunia Tentang Perempuan di Beijing, 1995 dalam Charles Kurzman (ed) Wacana Islam Liberal, I5 dan M. Syahrur, Iman dan Islam : Aturan-Aturan Pokok, xiv

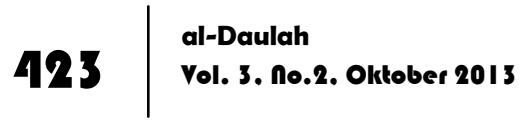


lebih dari itu terdapat sebagaian kalangan menganggap bahwa Syahrur adalah salah seorang yang merupakan antek-antek Yahudi dan Barat yang dibiayai untuk menyebarkan pemikiran yang dapat menyebabkan kehancuran persatuan umat Islam. Meskipun dia masih cukup beruntung karena tidak sampai mengalami keadaan seperti Nasr Hamid Abu Zaid yang harus rela meninggalkan negerinya, Mesir, karena pemikiran kontroversial yang dilontarkannya. ${ }^{56}$

Dari sini terlihat bahwa antusiasme dan pembelaanya yang begitu menggebu pada demokrasi tidak lebih sebagai upaya apologetik dan menunjukkan betapa Syahrur telah menderita uforia demokrasi sehingga melihat demokrasi sebagai suatu sistem yang nyaris tanpa cela dan -yang patut disayangkan adalah- dia mengggunakan justifikasi teologis untuk melakukan pembenaran atas pandangannya bahwa betapa idealnya konsep demokrasi tersebut.

Syahrur membayangkan bahwa dengan adanya demokrasi, dalam artian kebebasan mengungkapkan pendapat sebagaimana yang dia agungkan dalam sistem demokrasi, maka kejadiankejadian yang "kurang menyenangkan" yang menimpanya tidak akan pernah terjadi, seperti banyaknya kecaman yang ditujukan kepadanya sebagai pemecah belah umat Islam, karena perbedaan pendapat dalam demokrasi adalah merupakan suatu hal yang wajar bahkan merupakan keniscayaaan dan tulang punggung demokrasi sebagai konsekuensi dari kebebasan menyatakan pendapat dan berbicara. Syahrur membayangkan betapa pendapatnya yang kontroversial akan ditempatkan sebagai keragaman pemikiran yang tidak perlu mendapatkan label

\footnotetext{
${ }^{56}$ Nasr Hamid Abu Zaid adalah seorang staf pengajar pada Fakultas Sastra di Universitas Kairo yang gagal meraih gelar profesor karena buku-bukunya dianggap menngandung anasir ateisme dan juga dinaggap menghina nash-nash al-Qur'an, sunah Rasul, mencaci maki Imam Syafi'i, meneriakkan kebebasan berpikir, mengecam sikap tekstualis, menyebarkan paham sesat tentang zat Allah, menyerang al-Azhar, dan membela Salman Rusydi yang dihukumi murtad. Selain itu Nasr juga diajukan ke pengadilan agar istrinya di fasakh (dipisah secara paksa) karena Nasr Hamid Abu Zaid dianggap sudah murtad dari agamanya dan menentang ayat-ayat Allah. Baca Daud Rasyid, Pembaruan Islam dan Orientalisme dalam Sorotan, 46-47
} 
"berbahaya" dari orang-orang yang berbeda pemikiran dengannya jika sistem demokrasi diterapkan.

Terlepas dari pandangan Syahrur di atas, hal mendasar yang harus diapresiasi adalah fungsi pemikirannya yang mendobrak dan mengajarkan berpikir kritis dan ajakan untuk beragama dengan akal dan hati, selain konsepsinya tentang demokrasi religius.

\section{Konsep Negara Ideal Muhammad Syahrur}

\section{Struktur Dasar Negara Ideal}

Melihat konsep Syahrur tentang struktur dasar untuk membentuk negara, kita tidak akan menemukan hal baru kecuali pengulangan-pengulangan sebagaimana yang selama ini telah dipahami. Hal ini nampak dari pemaparannya bahwa untuk membentuk suatu negara diperlukan wilayah, adanya pembagian kekuasaan atau dalam bahasa sederhana adalah adanya pembagian tugas dalam masyarakat dan lain sebagainya, yang mana konsep seperti ini adalah merupakan konsep yang sudah banyak dibahas oleh para ahli tata negara sejak masa yang lalu.

Namun terlepas dari kekurangan dari konsep Syahrur di atas, negara demokratis, yang bagi Syahrur adalah sebuah negara dimana ada sebuah kondisi jalan tengah atau moderat dalam pola relasi timbal balik antara struktur-struktur yang heterogen, ${ }^{57}$ dapat mengantarkan umat Islam menjadi ummatan wasatan.

Dalam Islam istilah ini tertuang dalam al-Qur'an surat alBaqarah ayat 143, yang artinya: "Begitulah Kami jadikan kamu umat yang pertengahan, supaya kamu menjadi saksi atas (perbuatan) manusia dan Rasul menjadi saksi pula atas perbuatanmu. Tiadalah Kami jadikan engkau kiblat engkau yang dahulu itu, melainkan supaya Kami ketahui orang-orang megikut Rasul daripada orang yang kembali kepada kekafiran. Sesunguhnya yang demikian itu amat berat, kecuali atas orang-orang yang ditunjuki Allah. Allah tiada menyia-nyiakan keimanan

57 Syahrur, Tirani Islam, 194

\begin{tabular}{l|l}
425 & al-Daulah \\
Vol. 3. no.2. Oktober 2013
\end{tabular} 
kamu. Sungguh Allah Pengasih lagi Penyayang kepada manusia."(QS. Al-Baqarah: 143) 58

Dalam ayat di atas disebutkan bahwa kualifikasi umat yang baik adalah ummatan wasatan. Secara harfiah wasata berarti pertengahan atau moderat. Makna ini menunjuk pada pengertian adil- seimbang dalam takarannya. Dengan demikian, makna umat wasata adalah umat moderat. Posisinya berada di tengah-tengah agar dilihat oleh semua pihak dari semua penjuru. Posisi pertengahan menjadikan manusia tidak memihak ke kiri dan ke kanan, hal mana mengantar manusia berlaku adil. Posisi ini menjadikan umat Islam pada posisi ideal. ${ }^{59}$ Dari sini, negara yang meniscayakan adanya sebuah kondisi jalan tengah atau moderat dalam pola relasi timbal balik antara struktur-struktur yang heterogen, yang akan dapat mengantarkan umat pada kondisi moderat tersebut.

Keharusan penerapan demokrasi yang merupakan representasi syura pada masa modern di negara ideal dan juga keharusan menjadikan penerapan demokrasi dimasukkan ke dalam undang-undang negara, ${ }^{60}$ adalah sejalan dengan prinsipprinsip yang terdapat dalam Islam bahkan sudah menjadi tradisi yang hidup ditengah-tengah umat Islam. Pernyataan ini didukung oleh realitas sejarah, dimana pada masa nabi misalnya, ketika beliau membangun masyarakat Madinah, Piagam Madinah yang dibuat oleh Nabi sebagai perjanjian bersama antara kaum Muhajirin dan Ansar, yang merupakan kelompok mayoritas, dengan kaum Yahudi di Madinah, yang merupakan kelompok minoritas. Dalam perjanjian tersebut tidak ditemukan penyebutan negara Islam ataupun memberikan prioritas terhadap orang-orang mukmin. Ketiga kelompok yang terlibat dalam perjanjian tersebut sepakat untuk menjadi umat yang satu (ummatan wahidan) yang

\footnotetext{
58 Departemen Agama, al-Qur'an dan Terjemahnya, 17

${ }^{59}$ M. Qurais Shihab dalam Said Agil Siraj al-Munawar, Hukum Islam dan Pluralitas Sosial, (Jakarta: Paramadina, 2004), 17|- 172

60 Ibid, 206
} 
menjunjung tinggi persamaan, keadilan, pelestarian adat yang baik, kebebasan beragama, serta pembelaan terhadap tanah air. ${ }^{61}$ Satu hal yang lebih fundamental adalah ketika Nabi wafat pun tidak meninggalkan wasiat mengenai siapa yang akan meneruskan pemerintahan dan juga tidak ditemukan sebuah perintah atau wasiat Nabi untuk mendirikan sebuah "negara Islam" sebagaimana yang telah menjadi perbincangan serius umat pada masa sekarang. ${ }^{62}$

\section{Bentuk dan karakteristik Negara Ideal}

Konsep negara Islam ideal yang dicita-citakan Syahrur adalah sebuah negara, yang menurutnya, menjadikan demokrasi sebagai hal pokok yang harus ada dalam struktur negara, yang dibuktikannya dengan keharusan dari perangkat-perangkat militer untuk tunduk secara total kepada kekuasaan politik. Pendapat seperti ini, meskipun bagus, sebenarnya merupakan pengulangan dari konsep yang sudah mapan selama ini. Karena pemerintahan demokrasi adalah merupakan pemerintahan rakyat, dalam arti pemerintahan tersebut dibentuk berdasarkan pada kehendak rakyat secara bebas, yang diwujudkan melalui pemilu yang dilangsungkan secara bebas, baik melalui pemilihan pemimpin secara langsung maupun dengan cara memilih wakilwakil rakyat. Maka pada dasarnya pemegang kekuasaan tertinggi adalah rakyat. ${ }^{63}$ Oleh karena militer, sebagai benteng pertama keamanan negara, dimana pemegang kekuasaan negara ada pada kekuasaan politik sipil, tidak dapat dihindari, harus tunduk sepenuhnya pada kekuasaan politik.

Melihat pemaparannya bahwa bentuk negara Islam itu adalah tergantung dari konteks dimana negara tersebut berada ${ }^{64}$, serta

\footnotetext{
${ }^{61}$ Baca Teks Piagam Madinah di Ahmad Sukardja, Piagam Madinah dan Undang-Undang Dasar 1945, Kajian Perbandingan Tentang Dasar Hidup Bersama dalam Masyarakat yang Majemuk, (Jakarta: Universitas Indonesia, 1995), 47-57

${ }^{62}$ Abdurrahman Mas'ud, Pengantar dalam buku Suyuthi Pulungan,et al, Negara Bangsa VS Negara Syariah, (Yogyakarta: Gama Media, 2006), xiv

${ }^{63}$ Soehino, Ilmu Negara, (Yogyakarta: Liberty, 2000), 162-163

${ }^{64}$ Syahrur, Tirani Islam, 219
} 
pendapatnya bahwa negara Islam ideal adalah sebuah negara yang tidak mendasarkan legitimasinya dari para mufti melainkan dari rakyat, dapat disimpulkan bahwa negara yang dicita-citakanya adalah merupakan negara demokrasi. Sedangkan pendapatnya bahwa dalam negara tersebut tidak terdapat Haman atau penjaga hukum-hukum Tuhan, mengukuhkan keyakinan penulis bahwa negara tersebut bukanlah negara teokratis, melainkan "negara sekuler". ${ }^{65}$ Jadi dapat disimpulkan bahwa negara tersebut adalah sebuah negara sekuler yang menjadikan demokrasi sebagai dasar negara. Artinya bagaimana bentuk negara tersebut tidak ditentukan olehnya, apakah republik, atau yang lainya, namun yang penting baginya adalah negara tersebut adalah negara demokratis yang sekuler, dalam konsep Syahrur tentunya.

Pandangan di atas setidaknya menunjukkan bahwa negara Islam adalah bukan hanya dipahami sebagai sebuah negara yang hanya menerapkan hukuman potong tangan bagi pencuri ataupun melakukan hukuman rajam bagi pelaku perzinahan sebagaimana yang ditunjukkan oleh beberapa negara yang menyatakan diri sebagai negara Islam, namun dengan tidak memberlakukan kembali ajaran dan nilai-nilai hakiki Islam, melainkan dengan hanya mencukupkan diri pada penerapan "hukuman dalam Islam" yang disimbolkan dengan potong tangan dan rajam. Selain itu adanya kewajiban pemakaian jilbab atau cadar bagi perempuan, sering dijadikan sebagai dasar untuk menyebut suatu negara

\footnotetext{
${ }^{65}$ Menurut pemahaman Syahrur, negara sekuler adalah sebuah negara yang di dalamnya tidak terdapat penjaga hukum Tuhan, namun bukan berarti negara tersebut adalah sebuah negara yang tanpa agama karena negara tersebut dalam membuat sebuah keputusan tidaklah boleh melampaui batasan-batasan Tuhan yang dalam istilahnya dikatakan bahwa sesuatu yang haram tidak tunduk kepada voting. Baca Syahrur, Tirani Islam...., 217-2I8 Menutur Syahrur, negara sekular didirikan atas dasar sebagai berikut (I) tidak ada paksaan dalam memeluk agama (2) melawan kelaliman (3) menyelesaikan masalah dengan jalan musyawarah (4) memisahkan otoritas agama (ritus keagamaan) dari otoritas negara (5) memiliki aturan hukum etika umum (menyeluruh) (6) menetapkan batasan-batasan Allah yang sesuai dengan fitrah kemanusiaan (7) mengupayakan metode pembahasan ilmiyah, yang menghadirkan bukti-bukti nyata bagi legislasi dan perselisihan. Baca. Syahrur, Ibid, 218
} 
sebagai negara Islam meskipun negara tersebut dipimpin oleh pemimpin yang lalim dan raja-raja yang diktator.

Dengan konsepsinya tentang negara sekuler di atas, terlihat Syahrur ingin menyatakan bahwa yang dimaksud dengan negara Islam adalah sebuah negara yang sebesar mungkin mampu mewujudkan nilai-nilai luhur yang terdapat dalam Islam tanpa harus terpaku pada bentuk formal "negara Islam" sebagaimana pemahaman kaum puritan.

\section{Urgensi Demokrasi dalam Upaya Pembentukan Negara Ideal}

Pada masa setelah meninggalnya Rasulullah, hal yang menjadi masalah dan menjadi perdebatan sengit serta memilukan, meskipun kemudian berakhir dengan damai dengan terpilihnya Abu Bakar untuk memimpin kaum muslimin, adalah menentukan siapa pemimpin pengganti Nabi karena nabi sudah meninggal dunia, dan bukannya bagaimana agar jenazah nabi segera dimakamkan. Dalam perdebatan sengit itu juga terekam bahwa pada dasarnya hal yang menjadi "topik utama" adalah siapa yang paling berhak menjadi pemimpin, yang dalam hal ini berarti kualifikasi apa yang dijadikan dasar pijakan serta bagaimana cara memilih pemimpin yang baik. Ketiadaan petunjuk yang jelas dari Nabi mengenai bagaimana mekanisme suksesi kepemimpinan, kecuali dengan sistem musyawarah, telah menjadikan pertarungan logika dan retorika menempati posisi yang menentukan. Sehingga tidak terlalu mengherankan bahwa jika kemudian muncullah ungkapan bahwa seseorang dari kaum Ansar-lah yang lebih berhak menjadi pemimpin menggantikan Rasul, mengingat merekalah yang menolong Nabi dan kaum muslimin dengan memberikan perlindungan, tempat tinggal dan lain-lain ketika diintimidasi oleh kaum kafir Makah, sehingga kemudian Islam dapat berkembang sampai saat itu ${ }^{66}$

${ }^{66}$ Jamal al- Bana, Runtuhnya Negara Madinah, Islam Kemasyarakatan versus Islam Kenegaraan. (Yogyakarta: Pilar Media, 2005), 56

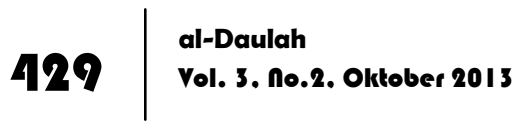


Tidak ingin kalah dengan retorika kaum Ansar, kaum Muhajirin yang merupakan keturunan Quraysyi adalah umat yang paling berhak menjadi pemimpin. Selain karena mereka termasuk umat yang pertama masuk Islam, teman pergaulan Rasul, dari itu, kaum muhajirin adalah termasuk umat yang pertama masuk Islam, jadi merekalah yang paling berhak menjadi pemimpin menggantikan Rasulullah. ${ }^{67}$ Peristiwa serupa, dan bahkan lebih memilukan, terjadi dan terulang dalam kasus yang lain seperti pada masa Ali dan Muawiyah, tentu dengan sedikit bumbu retorika.

Semua realitas yang mengemuka dalam bingkai perpecahan dan perselisihan diatas sebenarnya adalah dikarenakan umat Islam generasi awal tersebut kurang menyadari betapa berbahayanya ketidak sepahaman-politik yang mengancam, apabila mereka tidak secepatnya diorganisir dan diberi saluran institusi politik dengan petunjuk dan aturan yang jelas yang meliputi partai politik, mekanisme pemilihan dan parlemen. ${ }^{68}$

Jika realitas diatas dijadikan rujukan dengan mengatakan bahwa Islam adalah bersifat holistik sebagaimana yang banyak diungkap kaum puritan, maka haruskah kejadian sejarah di atas terulang dan menjadikan kaum muslim yang sudah terbelakang menjadi semakin terbelakang.

Dengan menggunakan konsep demokrasi yang dibawa Syahrur (demokrasi religius), kejadian diatas- menurut penulis tidaklah perlu terjadi dan terulang lagi. Mengingat dengan menggunakan teori demokrasi, mekanisme dari suksesi

\footnotetext{
67 Pada saat kaum Ansar sedang berkumpul dan terlibat pembicaraan yang serius mengenai pengganti Nabi di rumah Sa'ad Ibn 'Ubadah, mereka dikejutkan dengan kedatangan Abu Bakar, Umar dan Abu Ubaidah. Kemudian Abu Bakar bersaksi dan berdiri di hadapan orang-orang dan berkata: Sesungguhnya Allah Yang Maha Agung mengutus Muhammad dengan hidayah dan agama yang benar, kemudian mengajak kepada Islam, lalu Allah mengarahkan pikiran dan hati kita keada apa yang diserukan Nabi. Hai orang-orang Muhajirin, kami adalah orang yang pertama masuk Islam...dst. baca. Ibid, 57- 58

68 Radwan A. Masmoudi, Islam dan Demokrasi: Antara Masa Lalu, Masa Kini dan Masa Depan dalam Bernard Lewis, et al, Islam Liberalisme Demokrasi, Membangun Sinerji Warisan Sejarah, Doktrin, dan Konteks Global, Mun'im A Sirry (ed), (Jakarta: Paramadina, 2002), I 5
} 
kepemimpinan telah diatur secara memadai. Sehingga negara Islam -yang dalam konsep Syahrur adalah negara ideal- potensial menjadikan suksesi kepemimpinan sebagai sebuah dinamika dalam kehidupan bernegara yang sehat. Dengan adanya pemisahan kekuasaan antara legislatif, eksekutif dan yudikatif, proses check dan balance di antara ketiga lembaga pemerintahan tersebut akan mampu mencegah terjadinya praktik-praktik eksploitatif yang potensial. 69

Dari sini terlihat bahwa demokrasi adalah merupakan keniscayaan zaman yang berperan sebagai penopang manusia di mana manusia tidak lagi sekedar individu dari rakyat melainkan warga negara yang eksistensinya ditentukan oleh sejumlah hak yaitu hak-hak demokrasi, terutama hak memilih, mengawasi dan mencopot penguasa, disamping hak akan kebebasan menyatakan pendapat berkumpul, membuat partai, dan lain-lain. Dengan demikian demokrasi adalah sebuah keniscayaan untuk memungkinkan individu dalam masyarakat mendapatkan hakhak sebagai warga negara di satu sisi dan bagi para penguasa untuk mendapatkan legitimasi yang menopang kekuasaan mereka pada sisi yang lain. ${ }^{70}$

Negara ideal, yang oleh Syahrur diartikan dengan sebuah negara yang di dalamnya selain dijamin adanya kebebasan juga sebuah negara yang sudah melampaui level kesukuan atau kedaerahan dan semangat primordialisme, juga sebuah negara yang sudah mencapai level syu'ub. Dengan telah mencapainya masyarakat dalam sebuah negara pada level syu'ub71, maka kepentingan dari suku atau kelompok akan ditaruh dibawah kepentingan umum atau kepentingan bersama. Sedangkan kondisi

${ }^{69}$ Sadeq Jawad Sulaiman, Demokrasi dan Syura. Dalam Charles Kurzman (ed), Wacana Islam Liberal, Pemikiran Islam tentang Isu-Isu Global, (Jakarta: Paramadina, 200 I), I 26

70 Muhammad Abid al-Jabiri, Syura Tradisi Partikularitas Universalitas, terj. Mujiburrahman, (Yogyakarta: LKiS, 2003), 90-9।

71 Syu'ub, menurut Syahrur, secara sederhana dapat diartikan sebagai bangsa, yang di dalamnya terdiri dari berbagai macam suku dan kelompok dengan kebudayaan yang berbeda, namun mempunyai satu visi. Baca Syahrur, Tirani Islam, 85

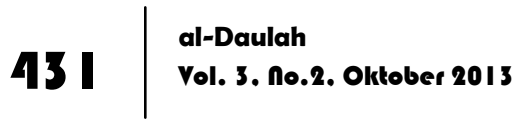


seperti ini, yaitu pencapaian masyarakat pada level syu'ub, menurut Syahrur, adalah hanya dengan melalui sistem demokrasi. Hal ini sekaligus memperlihatkan kecenderungan Syahrur yang pro negara bangsa (nation state).

Demokrasi model Syahrur ini, lebih jauh mampu berperan menjaga dan menjadikan prinsip-prinsip syura -seperti persamaan dan lain sebagainya- sebagai sebuah kenyataan yang benar-benar terwujud. Sehingga tidak ada lagi manusia diktator dan tidak ada lagi politik keberhalaan, yaitu yang berdasarkan pengkultusan terhadap seorang figur. Sehingga setiap pikiran yang dihasilkan dari telaah kritis bisa didengar tanpa rintangan dan setiap warga yang mempunyai kualifikasi mengenai syarat dan kemampuannya, dapat maju tanpa ada hambatan dalam meraih kekuasaan $^{72}$.

Selain daripada itu dengan dijaminnya kebebasan berekspresi sebagaimana yang telah dijelaskan terdahulu, dapat mendorong dalam pengembangan keilmuan mengingat dengan adanya kebebasan yang besar dalam eksplorasi pemikiran, maka akan dapat mengantarkan umat pada kondisi dinamis (tidak statis) dan tidak terjadi kebekuan pemikiran, sebagaimana yang telah terjadi dalam kasus sejarah fiqih.

Dengan adanya patokan bahwa penerapan demokrasi tidak akan melampaui batasan-batasan Tuhan, sebagaimana yang diterangkan dalam konsepsi Syahrur, akan dapat digunakan sebagai filter dalam penerapannya dalam kehidupan bernegara. Maka yang kemudian akan terjadi adalah bukan sebagaimana yang menimpa Amerika, ${ }^{73}$ dimana dengan penerapan demokrasi yang terjadi justru hukum Tuhan ditaruh dibawah level pendapat masyarakat, sehingga yang kemudian terjadi adalah hukumhukum non agama yang dilahirkan dalam parlemen.

72 Syaikh Muhammad al-Ghazali, Studi Kritis Atas Hadis Nabi SAW, (Bandung: Mizan, t.th.), 167

${ }^{73}$ Baca M. Amin Rais Pengantar dalam buku al-Maududi. Khilafah dan Kerajaan: Evaluasi Kritis atas Sejarah Pemerintahan Islam, (Bandung: Mizan, 1998), 26-27 
Terlepas dari kelebihan konsep di atas, sebenarnya ada yang cukup janggal dari konsepsi Syahrur diatas. Salah satunya adalah mengenai konsepnya yang mengatakan bahwa hukum yang dibuat tidaklah boleh melampaui hukum Tuhan, atau yang dalam istilah Syahrur adalah tidak boleh melampaui batasan-batasan Tuhan. Yang menjadi pertanyaan adalah siapa yang berhak menentukan bahwa suatu hukum yang dibuat tersebut bertentangan atau tidak dengan kehendak atau hukum Tuhan, apalagi jika hukum tersebut berkenaan dengan hukum yang memerlukan interpretasi mendalam. Apakah rakyat sebagaimana konsep Syahrur tentang kebebasan warga masyarakat dalam bertindak atau dengan bantuan suatu badan tertentu yang berhak mengatakan hitam dan putih berkenaan dengan hukum Tuhan, yang tentu saja hal ini bertentangan dengan konsepsinya bahwa negara Islam ideal adalah sebuah negara yang didalamnya tidak terdapat Haman atau penjaga hukum-hukum Tuhan.

Tampaknya Syahrur mengalami kerancuan dalam merumuskan teorinya. Disini terlihat bahwa dia tidak menyetujui konsep negara teokrasi, karena dapat mengekang kebebasan rakyat dalam eksplorasi pemikiran dan terlihat kekhawatiranya akan adanya persekongkolan antara kaum elit agama dengan penguasa sebagaimana yang terjadi di Eropa jaman pertengahan, dan kemudian Syahrur berkeinginan menggantinya dengan konsep negara Islam demokrastis. Namun tidak merumuskan dengan jelas mengenai siapa yang akan menentukan koridor terlarang atau tidak terlarang serta melampaui atau tidak melampaui ketetapan dan batasan hukum Tuhan.

\section{Penutup}

Demokrasi menurut Syahrur adalah praktik kebebasan yang dilakukan sekelompok menusia sesuai dengan otoritas pengetahuan, etika, estetika, adat istiadat, dan syari'at agama. Sistem politik dan pemerintahan ini menekankan pada musyawarah mufakat untuk menyelesaikan permasalahan yang 
dihadapi masyarakat dalam sebuah negara. Sistem ini merupakan representasi dari konsep syura dalam Islam pada masa modern dikarenakan nilai-nilai yang ada dalam syura telah teimplikasikan dalam konsep demokrasi ini, seperti musyawarah, persamaan kedudukan antar warga negara dan lain sebagainya. Menurutnya syura adalah bagian dari kehidupan yang tidak terlepas dari unsur perubahan. Adapun wujud syura tersebut pada abad modern ini adalah demokrasi.

Demokrasi mempunyai peranan yang sangat urgen dalam pembentukan negara ideal, yaitu sebuah negara yang mendasarkan legitimasinya pada rakyat dan bukan pada mufti serta tidak mengakui keberadaan haman atau penjaga hukumhukum Tuhan di dalam negara tersebut. Negara. Dimana demokrasi berperan sebagai media dalam pembentukan negara tersebut. Hal ini, tidak lain dikarenakan demokrasi yang meniscayakan perbedaan pendapat dan kepastian hukum mempunyai peranan yang sangat siknifikan dalam pengembangan ilmu pengetahuan yang sangat penting dalam negara ideal. Karena dengan kebebasan berpendapat dapat memberikan kesempatan setiap orang untuk berpendapat dan mengeksplorasi segenap pikirannya tanpa ada ketakutan. Kemajuan ilmu pengetahuan, sebagai konsekuensi dari kebebasan berpendapat tersebut, dapat mengantarkan sebuah negara menuju kemajuan peradaban dalam berbagai bidang. Selain itu demokrasi juga dapat mengharmonikan berbagai kepentingan dari warga negara yang berbeda-beda dengan tanpa melakukan penyeragaman namun dengan melakukan harmoni dari berbagai kepentingan yang berbeda tersebut. Sehingga keberadaan dan penerapan demokrasi bisa dikatakan suatu keniscayaan dalam upaya untuk membentuk suatu Negara ideal.

Adapun analisa hukum Islam terhadap pemikiran Muhammad Syahrur tentang urgensi demokrasi dalam upaya pembentukan negra ideal adalah secara umum, konsep Syahrur tersebut adalah dapat diterima dan pemikirannya tentang 
demokrasi adalah sejalan dengan nilai-nilai yang terdapat dalam Islam. Selain daripada itu, konsep negara ideal Syahrur dapat mengantarkan umat Islam menjadi "Ummatan Wasatan". Urgensi demokrasi yang ditawarkannya berpeluang mencegah timbulnya perselisihan diantara umat mengenai masalah kenegaraan, seperti peristiwa di Saqifah bani Saidah.

\section{Daftar Pustaka}

Abied, M. Aunul (ed). Islam Garda Depan Mosaik Pemikiran Islam Timur Tengah. Bandung: Mizan, 2001

Amirudin, M. Hasbi. Konsep Negara Islam Menurut Fazlur Rahman. Yogyakarta: UII Press, 2002

Anwar, M. Syafi'i. Pemikiran dan Aksi Islam Indonesia: Sebuah Kajian

Politik tentang Cendekiawan Muslim Orde Baru. Jakarta:

Paramadina, 1995

Assyaukani, A. Lutfi. Tipologi dan Wacana Pemikiran Arab

Kontemporer. Jurnal Paramadina, vol. 1, no.1, Juli-Desember 1998

Azhari, Muhammad Tahir. Negara Hukum, Suatu Studi tentang Prinsip-Prinsipnya Dilihat dari Segi Hukum Islam, Implementasinya Pada Periode Negara Madinah dan Masa Kini. Jakarta: Kencana, 2004

Bana (al-), Jamal. Runtuhnya Negara Madinah, Islam Kemasyarakatan versus Islam Kenegaraan. Yogyakarta: Pilar Media, 2005

Buraey (al-), Muhammad A. Islam Landasan Alternatif Administrasi Pembangunan, terj. Achmad Nashir Budiman. Jakarta: Rajawali, 1986

Chrismann, Andreas. Bentuk Teks (Wahyu) Tetap, Tetapi Kandungannya Selalu Berubah: Tekstualitas dan Penafsirannya dalam al-Kitab Wa al-Qur'an. Pengantar dalam Muhammad Syahrur. Metodologi Figh Islam Kontemporer. Yogyakarta: elSAQ Press, 2004 
Dault, Adhyaksa. Islam dan Nasionalisme, Reposisi Wacana Universal dalam Konteks Nasional. t.tp: Pustaka al-Kautsar, 2005

Departemen Agama. al-Qur'an dan Terjemahanya. Bandung: PT. Syamil Cipta Media, 2005

Ghazali (al-), Syaikh Muhammad. Studi Kritis Atas Hadis Nabi SAW. Bandung: Mizan, t.th.

Hakim, Atang Abd dan Jaih Mubarok. Metodologi Studi Islam. Bandung: Remaja Rosdakarya, 1999

Hizbut Tahrir Indonesia. Waspadai Gerakan Anti Syari'ah. Buletin Al-Islam

Iqbal, Mohammad. Figh Siyasah Kontekstualisasi Doktrin Politik Islam. Jakarta: Gaya Media Pratama, 2001

Ismail, Ahmad Syarqawi. Rekonstruksi Konsep Wahyu Muhammad Syahrur. Yogyakarta: elSAQ, 2003

Jabiri (al-), Muhammad Abid. Syura Tradisi Partikularitas Universalitas, terj. Mujiburrahman. Yogyakarta: LKiS, 2003

Ma'arif, M. Syafi'i. Islam Politik dan Demokrasi di Indonesia, dalam Bosco Carvallo dan Dasrizal. Aspirasi Umat Islam Indonesia. Jakarta: Lappenas, 1983

Masmoudi, Radwan A. Islam dan Demokrasi: Antara Masa Lalu, Masa

Kini dan Masa Depan dalam Bernard Lewis, et al. Islam Liberalisme Demokrasi, Membangun Sinerji Warisan Sejarah, Doktrin, dan Konteks Global. Mun'im A Sirry (ed). Jakarta: Paramadina, 2002

Mas'ud, Abdurrahman. Pengantar dalam buku Suyuthi Pulungan, et al. Negara Bangsa VS Negara Syari'ah. Yogyakarta: Gama Media, 2006

Mun'im, A. Rafiq Zainul. Metodologi Penafsiran Kontemporer Muhammad Syahrur, Jurnal Akademika Vol 18 No. 2. Maret 2006

Munawar (al-), Said Agil Siraj. Hukum Islam dan Pluralitas Sosial. Jakarta: Paramadina, 2004

Pulungan, J. Suyuthi. Figh siyasah, Ajaran Sejarah dan Pemikiran. Jakarta: RajaGrafindo Persada, 1994 
Rais, Amin. Pengantar dalam buku al-Maududi. Khilafah dan Kerajaan: Evaluasi Kritis Atas Sejarah Pemerintahan Islam. Bandung: Mizan, 1998

Sadjzali, Munawir. Islam dan Tata Negara Ajaran, Sejarah, dan Pemikiran. Jakarta: Universitas Indonesia, 1990

Soehino. Ilmu Negara. Yogyakarta: Liberty, 2000

Sukardja, Ahmad. Piagam Madinah dan Undang-Undang Dasar 1945, Kajian Perbandingan Tentang Dasar Hidup Bersama dalam Masyarakat yang Majemuk. Jakarta: Universitas Indonesia, 1995 Sulaiman, Sadeq Jawad. Demokrasi dan Syura. Dalam Charles Kurzman (ed), Wacana Islam Liberal, Pemikiran Islam tentang Isu-Isu Global. Jakarta: Paramadina, 2001

Suseno, Frans Magnis. Demokrasi dan Agama, dalam Soetjipto Wirosardjono. Dialog dengan Kekuasaan, Esai-Esai Tentang Agama, Negara dan Rakyat. Bandung: Mizan, 1995

Syahrur, Muhammad. Tirani Islam Genealogi Masyarakat dan Negara. Yogyakarta: LkiS, 1994

-------. Iman dan Islam: Aturan Aturan Pokok. Yogyakarta: Jendela, 2002

--------. Dialektika Kosmos dan Manusia, Dasar-Dasar Epistemology Qur'ani, terj. M. Firdaus. Bandung: Nuansa, 2004

-------. Dasar dan Prinsip Hermeneutika al-Qur'an Kontemporer. Yogyakarta: elSAQ Press, 2007

-------. Metodologi Figh Islam Kontemporer. Yogyakarta: elSAQ Press, 2010

Taranggono, Eko. Islam dan Demokrasi: Upaya Mencari Titik Temu. Jurnal al-Afkar, Edisi VI, tahun ke 5 : Juli-Desember 2002

Tasrif, Muh. Nalar Politik Arab-Islam (Telaah Terhadap Pandangan Muhammad 'Abid al-Jabiri), Jurnal Dialogia, Jurnal Studi Islam dan Sosial, vol. 3 No. 2 Juli- Desember 2005

Thaha, Idris. Demokrasi Religius, Pemikiran Politik Nurcholis Madjid dan M. Amin Rais. Jakarta: Teraju, 2004 